\title{
Histological Studies on Foetal Thyroid Gland of Developing Human Foetuses
}

\author{
Rajeev Mukhia, ${ }^{1}$ Dil Islam Mansur, ${ }^{2}$ Mahendra Raj Pandey, ${ }^{1}$ BK Taneja' \\ 'Department of Anatomy, Manipal College of Medical Sciences, Pokhara, Nepal, 'Department of Anatomy, Kathmandu \\ University School of Mediccal Sciences, Dhulikhel, Kavre, Nepal.
}

\begin{abstract}
Introduction

Thyroid gland is the first endocrine gland to develop. It is one of the organs of interest for researchers since a long time. Though, detailed study about adult thyroid is there in the literature but histological study of thyroid gland at different stages in the foetal period is far and few. The present study aims to assess the histogenesis of thyroid gland and also to correlate the functional activity with structural changes in thyroid gland.
\end{abstract}

\section{Methods}

The study was carried out on 30 foetal thyroid gland of known gestational age ranging from 10 to 38 weeks foetuses. The midline dissection of neck was done to expose the thyroid gland. After tissue processing, paraffin blocks were prepared. All sections were stained with HaematoxylinEosin stain.

\section{Results}

In the foetuses, below $12^{\text {th }}$ gestational week no colloid was detected in thyroid gland. First appearance of colloid was observed at $14^{\text {th }}$ gestational week. Parafollicular cells were found after $17^{\text {th }}$ gestational week. Capsule thickness and gland vascularity increased with advancement of gestational age. The size of the peripheral follicles is larger than the central follicles.

\section{Conclusions}

The study concluded the developmental stage of foetal thyroid as Precolloidal stage, Colloid formation stage, Follicular stage and Maturation stage in different gestational weeks.The knowledge on the growth and differentiation of foetal thyroid will be helpful to the clinicians to judge the thyroid structure in preterm babies.

Keywords: histogenesis; gestational age; thyroid follicles.

Correspondence: Dr. Rajeev Mukhia,Department of Anatomy, Manipal College of Medical Sciences, Pokhara, Nepal. Email: rajeev.mukhia@manipal.edu.np. Phone: +977-9845100285. 


\section{INTRODUCTION}

Thyroid gland is the first endocrine gland to develop about fourth week of gestation. ${ }^{1}$ The thyroid primordium begins to develop as an endodermal mass in the posterior part of the primitive tongue at the foramen cecum. ${ }^{2}$ After formation, the endodermal mass begins to migrate caudally towards the anterior aspect of pharynx in the midline and remains connected to the foramen cecum by the thyroglossal duct. ${ }^{3}$ By approximately the fifth week of gestation, the thyroglossal duct begins to break down and the thyroid mass becomes isolated from the tongue. As the thyroid mass descends, it starts to form a bi-lobed structure. Later by the seventh week of gestation it migrates anterior to the hyoid bone and larynx to reach its final destination in front of the trachea. By the time, thyroid gland has almost acquired its final shape with two lateral lobes connected inferiorly by a isthmus. The endodermal tissue derived from the foramen cecum will gives rise to the numerous follicles of the thyroid gland. ${ }^{4-6}$

The foetal thyroid function is dependent on the embryogenesis, differentiation and maturation of the thyroid gland. ${ }^{7}$ The thyroid hormones are necessary for regulating the basal metabolic rate, somatic growth, psychic growth, calcium metabolism and circadian rhythm. ${ }^{8,9}$ Though, studies on foetal thyroid is available in previous literatures the studies of the foetal thyroid have still a large scope for researchers.

\section{METHODS}

The cross-sectional study was carried out on 30 foetal thyroid gland in the Department of Anatomy, Manipal College of Medical Sciences, Pokhara from March 2019 to April 2020. After ethical committee approval and permission from the concerned authorities of the Institute, the human foetuses aged between $10^{\text {th }}$ to $38^{\text {th }}$ gestational weeks were collected and preserved in $10 \%$ formalin. The age of foetuses was calculated from the crown rump length and crown heel length. The foetuses included spontaneous aborted and still born foetuses. Cases with twins or any congenital anomalies were excluded in the study. The foetuses were divided into eight groups according to their gestational age (Table-1). The midline dissection of the anterior aspect of neck was done to expose the thyroid gland. The infrahyoid muscles along with surrounding connective tissue were separated and the bi-lobed thyroid gland was removed. The thyroid tissue were subjected to routine processing by dehydration in graded alcohols, clearing in xylol and were embedded in paraffin. Sections of 5 microns thickness were cut with rotatory microtome and stained with Haemotoxylin \& Eosin stain. The histological features were observed using a compound light microscope and photography was taken with digital camera. All the digital images were correlated with the gestational age.

\begin{tabular}{|c|c|c|}
\hline \multicolumn{3}{|l|}{$\begin{array}{l}\text { Table 1. The foetuses were categorized into eight } \\
\text { groups according to their gestational age. }\end{array}$} \\
\hline Groups & Gestational age & Number of foetuses \\
\hline I & $10-12$ weeks & 3 \\
\hline II & $13-16$ weeks & 3 \\
\hline III & $17-20$ weeks & 4 \\
\hline IV & $21-24$ weeks & 4 \\
\hline V & $25-28$ weeks & 4 \\
\hline VI & $29-32$ weeks & 4 \\
\hline VII & $33-36$ weeks & 4 \\
\hline VII & $37-40$ weeks & 4 \\
\hline
\end{tabular}

\section{RESULTS}

The group wise histological observation of thyroid tissue was done under 10X compound light microscope.

\section{Group I $-10^{\text {th }}$ to $12^{\text {th }}$ gestational weeks (g.w.):}

In the foetuses of $10^{\text {th }}$ to $12^{\text {th }} \mathrm{g} . \mathrm{w}$. the thyroid 
gland was covered with a thin capsule. The centre of the gland showed large number of clusters and cords of epithelial cells. The lining epithelium was cuboidal and nucleus was darkly stained. Some of the thyroid follicles were oval to round shaped. Follicles at the periphery of gland were larger in size. Large number of blood vessels with rich vascularity at the periphery was seen. At this stage no colloid was detected. Hence this is called precolloid stage (Figure 1).

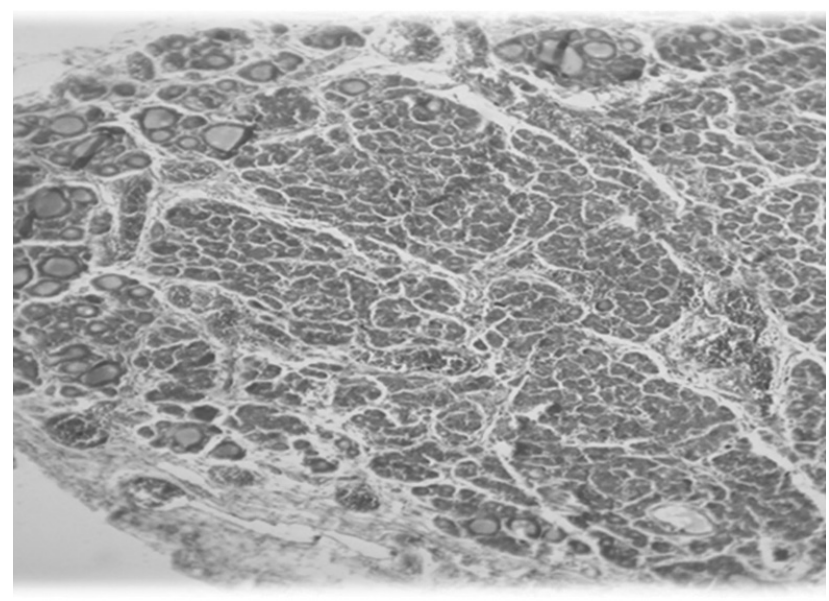

Figure 1. Foetal thyroid at $10^{\text {th }}$ to $12^{\text {th }}$ gestational weeks (precolloidal stage).

\section{Group II $-13^{\text {th }}$ to $16^{\text {th }}$ gestational weeks (g.w.):}

In the foetuses of $13^{\text {th }}$ to $16^{\text {th }} \mathrm{g} . \mathrm{w}$. the thyroid showed increase in capsule thickness and vascularity. Blood vessels invading the gland along with septa were seen. The septa divided the gland into incomplete lobules. The follicles showed progressive differentiation inwards from periphery of the gland. The centre of the gland still contained clusters and cords of epithelial cells and very few follicles were seen. The shape of follicles was round to oval. Follicular cells were simple cuboidal with darkly stained nuclei. Lightly stained thin rim of colloid material was present in few developing follicles. Hence this is called colloid formation stage (Figure 2).

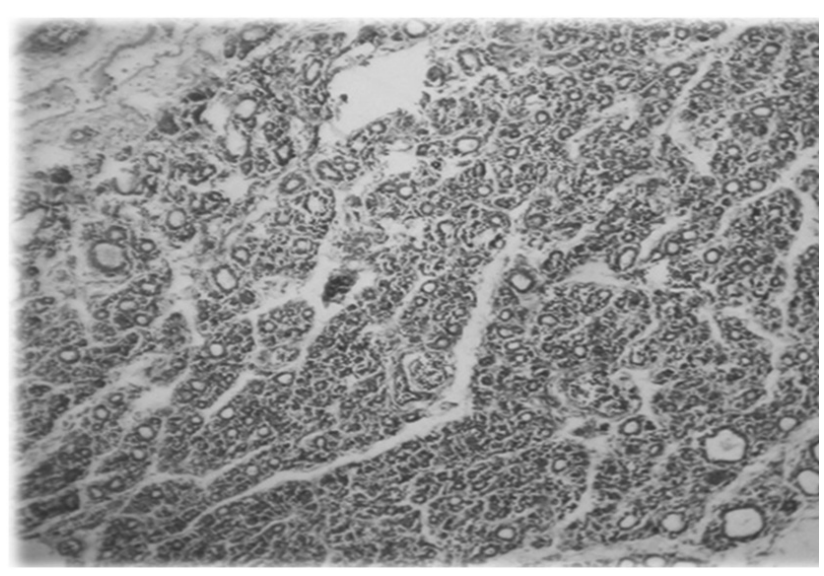

Figure 2. Foetal thyroid at $13^{\text {th }}$ to $16^{\text {th }}$ gestational weeks (Colloid formation stage).

\section{Group III $-17^{\text {th }}$ to $20^{\text {th }}$ gestational weeks (g.w.):}

In the foetuses of $17^{\text {th }}$ to $20^{\text {th }} \mathrm{g}$.w. the capsule was well developed with increased vascularity of gland. The peripheral and central follicles showed more increase in number than the previous stage. In the central core of the gland, developing follicles were seen which were very small in size with or without a lumen. Abundant sinusoids were present. The parafollicular cells or $C$ cells were noted at this stage. Hence, this stage was considered as folliculogenesis stage (Figure 3).



Figure 3. Foetal thyroid at $17^{\text {th }}$ to $20^{\text {th }}$ gestational weeks (Follicular stage).

\section{Group IV $-21^{\text {st }}$ to $24^{\text {th }}$ gestational weeks (g.w.):}

In the foetuses of $21^{\text {st }}$ to $24^{\text {th }} \mathrm{g}$.w. thick connective 
tissue septa along with blood vessel invading the gland were seen, but these septa did not give the gland typical lobular appearance as they were incomplete septas. More number of mature thyroid follicles was seen at this stage. The epithelial cells were cuboidal with centrally placed nucleus. Vascularity was increased amongst the follicles. The presence of colloid and its affinity with acidic dye, the secretory activity of the gland was more judged at this stage. Hence this stage was considered as secretory stage. The parafollicular cells or $\mathrm{C}$ cells were noted.

\section{Group V $-25^{\text {th }}$ to $28^{\text {th }}$ gestational weeks (g.w.):}

In the foetuses of $25^{\text {th }}$ to $28^{\text {th }}$ g.w. thyroid tissue was almost similar to that of previous stage, only size of follicles and vascularity was seen to be increased.

\section{Group VI $-29^{\text {th }}$ to $32^{\text {nd }}$ gestational weeks (g.w.):}

In the foetuses of $29^{\text {th }}$ to $32^{\text {nd }}$ g.w. the thyroid tissue showed increase in number and size of follicles with darkly stained colloid materials in the follicles. In some follicle colloid appeared irregular and eroded in the portion alongside the follicular cells. The parafollicular C cells were also noted during this stage.

\section{Group VII $-33^{\text {rd }}$ to $36^{\text {th }}$ gestational weeks (g.w.):}

In the foetuses of $33^{\text {rd }}$ to $36^{\text {th }}$ g.w. the thyroid tissue showed increased vascularity throughout this stage. Follicles were full of colloid material in the lumen. This stage shows increased synthesis as well as excretory activity of the gland.

\section{Group VIII $-37^{\text {th }}$ to $40^{\text {th }}$ gestational weeks (g.w.):}

In the foetuses of $37^{\text {th }}$ to $40^{\text {th }}$ g.w. the thyroid tissue was more or less similar to that of adult. Hence this stage was considered as mature stage (Figure 4).

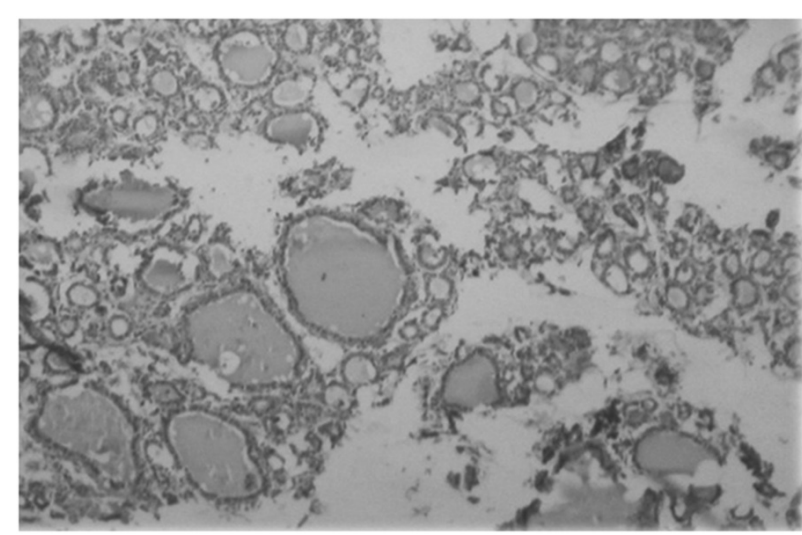

Figure 4. Foetal thyroid at $37^{\text {th }}$ to $40^{\text {th }}$ gestational weeks (Mature stage).

\section{DISCUSSION}

Numerous previous studies dealing with the growth and development of thyroid gland in human foetuses with respect to the gestational weeks have been limited to short periods of gestation. Our studies deal with the qualitative information of the thyroid gland from early to late gestational weeks of developing foetuses. According to Ham AW and Carmack DH, at $12^{\text {th }}$ gestational week, the capsule was very thin with less number of blood vessels but as the gestational age advances, the capsule became thicker and thyroid gland becomes more vascular. ${ }^{10}$ This finding was similar with the findings of the present study. According to Potter EL, during histogenesis of human thyroid, the solid epithelial cords gradually gets organized to form small follicles which later become hollowed out and filled with colloid like materials. The cytoplasm also bulges into the lumen of the gland. The follicles are larger at the periphery of lobules. ${ }^{11}$ In the present study the thyroid follicles differentiation started from the periphery of the gland and extended centrally, as the periphery of the gland was more vascular than the centre throughout the gestational age of foetus. This findings was in agreement to the findings reported by Potter EL. ${ }^{11}$ 
In the present study thin rim of colloid appeared in the developing thyroid follicles of 13-16 gestational weeks' foetuses and increased as the gestational age increases. Similar findings were observed in the study done by Anupriya A and Kalpna R. ${ }^{12}$ In the foetal thyroid tissue, the folliculogenesis stage was observed by Gaikwad JR in between $14^{\text {th }}-20^{\text {th }}$ gestational week foetuses. ${ }^{13}$ Hamilton also noted the follicular stage from $14^{\text {th }}$ gestational week foetuses. ${ }^{14}$ The above findings were almost similar to the findings of present study in which the folliculogenesis stage was observed between $13^{\text {th }}-20^{\text {th }}$ weeks. Bocian sobkowska J. noted that, the stage of massive folliculogenesis and gradual accumulation of colloid appeared between $10^{\text {th }}-18^{\text {th }}$ gestational week foetuses which is contradiction to the present study. ${ }^{15}$

Arthur WH reported that the colloid is often seen to have shrunken away from the follicular epithelium in such a way as to present a serrated rather than a smooth outline, when the gland is active. ${ }^{16}$ These results corroborate with the present study findings. In present study from $25^{\text {th }}$ week onward, the colloid appeared irregular and eroded at periphery along the apices of follicular cells of the thyroid gland. These findings are in accordance with the study done by Junqueira IC. ${ }^{17}$ In the foetuses of $37^{\text {th }}$ to $40^{\text {th }} \mathrm{g.w}$. the thyroid follicles showed full maturation and were more or less similar to that of adult.These results correlate well with the findings studied by Brown R. ${ }^{18}$

Hamilton 1972 divided the maturation of thyroid follicles into 3 stages. ${ }^{14}$

1. The precolloidal stage - 7-13 weeks

2. The colloid formation stage - 13 to 14 weeks

3. The follicular stage - 14 wks onwards.
The present study findings correlate with above findings done by Halminton and in addition we have included the mature stage (thyroid tissue of $37^{\text {th }}$ to $40^{\text {th }} \mathrm{g}$.w. fetuses).

To the best of our knowledge, this study has attempted to investigate the histological features of foetal thyroid gland from early to late gestational age. For understanding the histogenesis of the foetal thyroid gland at different gestational age, a large sample size is required and a detailed description and explanation of the development of parenchymal and vascular components by Immunohistochemistry is most essential.

\section{CONCLUSIONS}

The histological findings of the present study on foetal thyroid conclude that Precolloidal stage was seen between 10-12 gestational week, Colloid formation stage was between 13-16 gestational weeks, Follicular stage was from 17-20 week onwards and Maturation stage was between 37-40 gestational week foetuses. The size of the peripheral follicles is larger than the central follicles. The study gives the knowledge on thyroid growth and differentiation in different gestational ages. This knowledge will be helpful to the clinicians to judge the thyroid structure in preterm babies.

\section{ACKNOWLEDGEMENTS}

We would like to expresses special thanks to all the faculties and non-teaching staff members of Anatomy Department and Obstetrics and Gynaecology Department, MCOMS, Pokhara for their support. 


\section{REFERENCES}

1. Moore KL, Persaud TV. Before We Born: Essentials of Embryology and Birth Defects. Thyroid gland. 7th edition, USA: Saunders Elseveir. 2008;109-11.

2. Schoenwolf GC, Larsen WJ. Larsen's Human Embryology, 5th edition, Philadelphia, PA: Elsevier/Churchill Livingstone; 2015; 461-62

3. Sadler TW, Langman J. Langman's Medical Embryology, 12th edition, Philadelphia, PA: Wolters Kluwer Lippincott Williams \& Wilkins; 2012; 27475.

4. Zoeller RT, Crofton KM. Thyroid hormone action in fetal brain development and potential for disruption by environmental chemicals. Neurotoxicology. 2000; 21:935-45.

5. Park SM, Chatterjee VK. Genetics of congenital hypothyroidism. J Med Genet. 2005; 42:379-89.

6. Contempre B, Jauniaux E, Calvo R. Detection of thyroid hormones in human embryonic cavities during the first trimester of pregnancy. J Clin Endocrinol Metab. 1993; 77:1719-22.

7. Sylvia LA, Kalman $\mathrm{K}$, Ferenc $\mathrm{AL}$, Istvan D, Calvin E. Human F, et al. Adenohypophysis histological and immunolocytohemical analysis. Neuroendocrinology. 1986;34:308-16.

8. Kratzsch J, Pulzer F. Thyroid gland development and defects. Best Pract Res. Clin Endocrinol Metab. 2008;22(1):57-75.

9. Patel J, Landers K, Li H, Mortimer RH,
Richard K. Thyroid hormones and foetal neurological development. Journal of Endocrinology. 2011;209:1-8.

10. Ham AW and Carmack DH. Histology, 8th edition. J B Lippincott Company. Philadelphia and Toronto. 1979;801-02.

11. Potter EL. Pathology of the Fetus and the Infant. Thyroid gland. 2nd edition. Chicago Year Book Medical. 1961;320-23.

12. Anupriya A, Kalpna R. Morphological and histological features of human foetal thyroid gland. Int J Sci Stud. 2016;3(10):136-40.

13. Gaikwad JR, Dope SA, Joshi DS. Histogenesis of developing human thyroid. Indian Medical Gazette. 2012;57-61.

14. Hamilton WJ, Boyd, Mossman HW. Thyroid Gland. Human Embryology, 5th edition. London, Williams and Wilkins Company. 1971;323-326.

15. Bocian Sobkowska J, Wozniak W, Malendowicz LK. Morphometric studies on the development of human thyroid gland. The late foetal life. Histol Histopathol. 1997;12:79-84.

16. Arthur WH. The System of Endocrine Glands. Histology, 6th edition. Philadelphia and Toronto, JB Lippincott Company. 1969;810-56.

17. Junqueira LC, Carneivo J. Basic Histology, Text and Atlas, 11th edition. McGraw Hill Company. 2005;411-15.

18. Brown RS, Larson PR. Thyroid gland development and disease in infancy and childhood. In: Thyroid Disease Manager, Philadelphia, Saunders. 2005;11-19.

Citation: Mukhia R, Mansur D, Pandey M, Taneja BK. Histological Studies on the Foetal Thyroid Gland of Developing Human Foetuses. JCMS Nepal. $2021 ; 17(1) ; 75-80$. 